\title{
Quiste de Gartner. Hallazgos por resonancia magnética
}

\author{
Gartner's cyst. MRI findings \\ David Hernández Villeda, ${ }^{*}$ Karen Dalton Ceballos, ${ }^{*}$ Verónica Argüello Ramírez, * \\ Ariadna Hernández Dehesa, ${ }^{*}$ María de Guadalupe Gómez Pérez ${ }^{\ddagger}$
}

Femenino de 31 años de edad que refiere abultamiento en región periuretral asociado con datos de disuria de dos semanas de evolución. Acude a médico particular, el cual refiere tumefacción parauretral con extensión a pared vaginal anterior y solicita estudio de resonancia magnética de pelvis contrastada, en la que se observan imágenes saculares bien delimitadas hipointensas en la secuencia $\mathrm{T} 1$ e hiperintensas en T2, de aspecto agrupado, que tras la aplicación de medio de contraste no presentan realce significativo, localizadas en el muro anterior del tercio distal de vagina con diámetros aproximados en el plano sagital de $1.9 \mathrm{~cm}$, coronal $3.4 \mathrm{~cm}$ y axial $3.5 \mathrm{~cm}$, situadas a $1.1 \mathrm{~cm}$ del introito vaginal y a $3 \mathrm{~cm}$ del cérvix uterino. La uretra se observa respetada sin datos de disrupción de los esfínteres. Impresión diagnóstica: imágenes quísticas en tercio distal y anterolateral de vagina que sugieren la posibilidad de quiste de Gartner (Figuras 1 y 2).

Los conductos de Gartner se desarrollan a partir de los restos vestigiales del conducto mesonéfrico o conductos de Wolff. ${ }^{1}$ Los conductos derivados de los procesos mu-

Figura 1:

Resonancia magnética de pelvis axial (A) potenciada en T2 y (B) T2 FAT SAT. Se observan imágenes ovoideas de aspecto quístico que se localizan en el espesor de la pared vaginal anterolateral, sin disrupción del esfínter urinario.
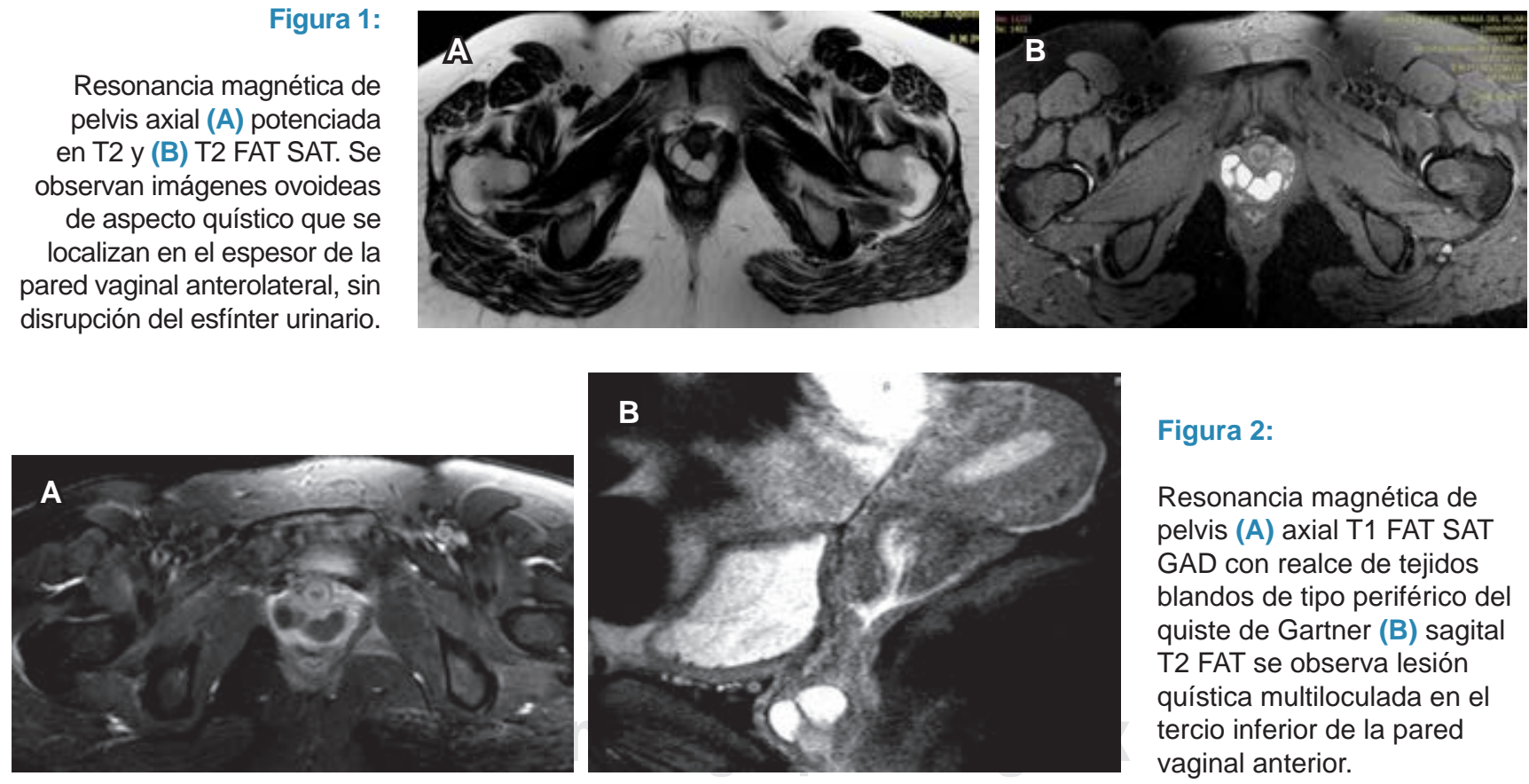

* Médico Residente.

‡ Profesora Titular.

Curso de Alta Especialidad Resonancia Magnética Corporal, Hospital Ángeles Pedregal. Ciudad de México.
Correspondencia:

David Hernández Villeda

Correo electrónico: drhernandezvilleda@hotmail.com

Aceptado: 14-06-2019.

www.medigraphic.com/actamedica 
llerianos y mesonéfricos tienden a ubicarse a lo largo de la porción anterolateral de la vagina, pero se pueden encontrar casi en cualquier sitio dentro de las paredes vaginales. El quiste del conducto de Gartner puede estar asociado a anomalías de la vía urinaria. ${ }^{1,2}$

Histológicamente, los quistes del conducto mesonéfrico están revestidos por epitelio columnar o cúbico no mucinoso. El quiste del conducto de Gartner se puede diferenciar de quistes mullerianos por la presencia de membrana basal y una capa de músculo liso. Sin embargo, una clara diferencia puede ser sólo por la tinción de histoquímica. ${ }^{3}$

Los quistes del conducto de Gartner suelen ser pequeños y clínicamente asintomáticos, pero a veces su tamaño es tan grande que producen síntomas. Los estudios de imagen son indispensables para realizar un diagnóstico diferencial adecuado entre el quiste de Bartholin el divertículo uretral y los cistoceles como los principales diferenciales, siendo el divertículo uretral el principal, el cual se presenta en los dos tercios distales de la pared anterior de la vagina. Estos divertículos suelen estar confinados a las paredes uretrales en contacto directo con los esfínteres del meato urinario. Los quistes de Bartholin típicamente varían de 1 a $4 \mathrm{~cm}$ de diámetro y se localizan en la porción posterolateral de la vagina inferior. ${ }^{4}$

\section{REFERENCIAS}

1. Fielding JR, Brown DL, Thurmond AS. Gynecologic imaging. Philadelphia, EUA: Elsevier Inc.; 2011. pp. 192-198.

2. Arumugam A, Kumar G, Si L, Vijayananthan A. Gartner duct cyst in pregnancy presenting as a prolapsing pelvic mass. Biomed Imaging Interv J. 2007; 3 (4): e46.

3. Hahn WY, Israel GM, Lee VS. MRI of female urethral and periurethral disorders. AJR Am J Roentgenol. 2004; 182 (3): 677-682.

4. Hagspiel KD. Giant Gartner duct cyst: magnetic resonance imaging findings. Abdom Imaging. 1995; 20 (6): 566-568. 